\title{
A COMPREHENSIVE FRAMEWORK FOR EVALUATING KEY PROJECT REQUIREMENTS
}

\author{
Li-Ren YANG ${ }^{\mathrm{a}}$, Jieh-Haur CHEN ${ }^{\mathrm{b}}$, Chung-Fah HUANG \\ ${ }^{a}$ Tamkang University, 151 Ying-chuan Rd., Tamsui, Taipei 251, Taiwan \\ ${ }^{b}$ Construction Engineering and Management, National Central University, No. 300, \\ Jhongda Rd, Jhongli 32001, Taiwan \\ ${ }^{c}$ National Kaohsiung University of Applied Sciences, 415 Chien-Kung Rd., Kaohsiung 807, Taiwan
}

Received 03 Aug 2011; accepted 26 Jan 2012

\begin{abstract}
Requirements definition affects work performed in subsequent phases of a project. Thus, the compliance with requirements is crucial to the success of a project. The primary objective of this research was to develop a comprehensive framework for evaluating key building project requirements. The second objective was to identify and prioritize important project requirement using the analytical network process (ANP). The third objective was to examine the impact of requirement completeness on project success using structural equation model (SEM) analysis. A four-phase approach was employed to achieve the goals. The results suggest that building programming and site information have a higher priority in requirement definition than project control, project strategy, and project design parameter. The findings also indicate that requirement completeness may contribute significantly to building project success in terms of schedule success, cost success, quality performance, and overall benefit.
\end{abstract}

Kewords: project requirements; requirements definition; project performance; ANP; SEM.

Reference to this paper should be made as follows: Yang, L.-R.; Chen, J.-H.; Huang, C.-F. 2013. A comprehensive framework for evaluating key project requirements, Journal of Civil Engineering and Management 19(Supplement 1): S91-S105. http://dx.doi.org/10.3846/13923730.2013.801903

\section{Introduction}

Many studies have shown that preproject planning effort may contribute to project performance in terms of cost, schedule, and operational characteristics (CII 1995; Griffith, Gibson 1995; Griffith et al. 1999; Sobotka, Czarnigowska 2005). Thus, preproject planning process is critical to the success of any capital facility project. The development of project requirements definition is one of the major subprocesses. It is the process by which projects are defined and prepared for execution (Cho, Gibson 2001). Additionally, it is the stage where project risk assessments are undertaken and the specific project execution methods are analyzed. Success during the detailed design, construction, and start-up phases of a project is highly dependent on the level of effort expended during this stage (Cho, Gibson 2001; Yang, Wei 2010).

In recent years, there has been a growing trend towards increased preproject planning effort on Architect/ Engineering/Construction $(\mathrm{A} / \mathrm{E} / \mathrm{C})$ capital facility projects. Some construction organizations adopt the best industry practices for project planning in the attempt to reduce the cost and schedule of a project. These compa- nies also examine their operations for ways to improve stakeholder satisfaction. However, since the importance of practices can be rather intangible, this has slowed the adoption of project planning practice. Accordingly, the importance of project planning has been one of the major issues for both industry and academic fields. Many studies indicated that one of the major challenges in construction management is the definition of project requirements (Radujković et al. 2010; Toor, Ogunlana 2010). In order to understand the issue, there is a need for quantification of prioritization of project requirements. Research on prioritization of project requirements should offer guides to project planning process.

Requirements definition and management (RDM) is the term used to describe the process of eliciting, documenting, analyzing, prioritizing, and agreeing on requirements, and then controlling, managing, and overseeing changes and risk (Oberg et al. 2000; Zowghi 2002). Requirements quality affects work performed in subsequent phases of a project. Thus, the compliance with requirements is crucial to the success of a project. The building sector suffers from poor or incomplete requirements

Corresponding author: Li-Ren Yang

E-mail: iry@mail.tku.edu.tw 
definition (Gibson et al. 1997; Cho et al. 1999). Early planning in many cases is not performed well in the construction industry (Cho, Gibson 2001). While many studies have promoted project planning as a means to enhance project performance, very few published studies in construction have explored the importance of project requirements from the perspectives of major stakeholders. Additionally, there is little evidence to support the relationships between levels of requirements definition and project performance. Empirical evidence that supports the importance of building project requirements is lacking. Thus, developing such support will illustrate the benefits of preproject planning. The primary objective of this research was to develop a comprehensive framework for evaluating key building project requirements. Analytical network process has been used to construct the framework in this study. The second objective was to identify and prioritize important project requirement using the ANP. The third objective was to examine the impact of requirement completeness on project success. In addition, this research employed both questionnaire survey and interview methods for data collection. A fourphase approach was used to measure the prioritization of building project requirements and explore the benefits of requirements definition.

\section{Literature Review}

A considerable body of research has been conducted on planning in the $\mathrm{A} / \mathrm{E} / \mathrm{C}$ industry. Much of the project/construction management literature relevant to this research is associated with the use of planning tools, guides to project planning, and the expected benefits associated with planning. Concerning the use of planning tools, Dumont et al. (1997) focused on developing a tool for assessing the levels of project definition. The tool, project definition rating index (PDRI) for Industrial Projects, can assist in calculating a total score representing the level of project definition. Cho and Gibson (2001) introduced the PDRI for building projects. Their research concluded that the PDRI is also an effective tool that applies to building projects. Heesom and Mahdjoubi (2004) investigated trends of four-dimensional computer aided design (4D CAD) applications for construction planning. They developed a model to identify the attributes required for use with each of the various applications of 4D CAD simulations. Ahmed et al. (2003) explored the applicability of quality function deployment (QFD) in the civil engineering capital project planning process. The findings suggested that QFD can be employed in the project planning process as a road map to keep track of the original requirements and facilitate good communication across the hierarchy. Additionally, it is also a useful tool for evaluating project alternatives. Ozdoganm and Birgonul (2000) built a decision support framework for project planning. They stated that the decision support framework can help project companies to define the risk sharing scenarios under which a project becomes viable and identify effective risk mitigation strategies. Gidado (2004) proposed a simple systemic approach that can be used in practice to improve and standardize the process of the prime contractor's planning of construction projects. Their work concluded that the implementation of the system of pre-construction planning may produce value in project system implementation. Furthermore, Laufer et al. (1999) developed a valuable tool to manage the decision-making process during the planning of a project. Gibson et al. (1995) also presented a validated process map describing the major subprocesses of preproject planning. Finally, Islam and Faniran (2005) developed a structural equation model (SEM) for quantifying the influence of situational factors in project environments. The findings indicated that the project environment has a dominant significant influence on the potential effectiveness of project planning efforts. In summary, above prior studies indicated that project planning plays an important role in construction.

While the above authors promoted the adoption of planning tools, other researchers have also been active in exploring the relationships between planning and project outcomes. Several researchers have identified the importance of planning and its impacts on the performance of capital facility projects or construction organizations. Kaka et al. (2003) evaluated the effects of project planning on the cost flow curves. Lee et al. (2005) examined the relative impacts of selected practices on project cost and schedule. They argued that pre-project planning is one of the critical practices indicating dominant impact on both cost and schedule performance. Hamilton and Gibson (1996) focused on measurement and benchmarking of the preproject-planning process for capital construction. The study concluded that a complete scope definition prior to project execution may contribute to project success. Griffith and Gibson (2001) identified the important characteristics of alignment during the preproject phase of industrial capital projects. The results suggested that alignment effort has a positive effect on project performance. Handa and Adas (1996) illustrated a methodology for predicting the level of organizational effectiveness in construction firms. The results indicated that level of planning by management is highly significant in predicting the level of organizational effectiveness in the construction firms. Finally, a study conducted by Construction Industry Institute (CII) indicated that higher levels of preproject planning effort may result in substantial cost and schedule savings (CII 1995).

Requirements definition is an important component of effective project planning. The literature stated that the problems related with requirements definition are one of the main reasons for project failures (Radujković et al. 2010; Toor, Ogunlana 2010). Resarch suggested that most of the project requirements were difficult to identify and some were not clear and well organized (Oberg et al. 2000 ). Prior research also indicated that $40 \%$ of the requirements generate rework during the project life cycle (Zowghi 2002). It is evident that the earlier a problem 
is detected during the preproject planning phase, many other problems are minimized in the follwing phases. Thus, requirements definition is often cited as one of the most important, but difficilt, phases of a project (Brooks 1987). The results of previous studies indicated a correlation between requirements definition effort and project performance (Damian, Chisan 2006; Procaccino et al. 2002; Brooks 1987; Kauppinen et al. 2004; Herbsleb, Goldenson 1996; Huang, Hsueh 2010; Radujković et al. 2010; Toor, Ogunlana 2010; Yang et al. 2011).

A review of the literature suggests that the use of project planning as a means to enhance project performance has been widely supported. Generally, many researchers have argued that planning provides significant benefits to projects (Laslo 2010; Görög 2009; Winch, Kelsey 2005; Wyk et al. 2008; Kwak, Smith 2009; Reed, Knight 2010; Artto et al. 2008; Hanna, Skiffington 2010). Prior research have also indicated that increased levels of scope definition during the preproject planning phase may improve the accuracy of cost and schedule estimates as well as the probability of meeting or exceeding project objectives (Griffith, Gibson 1995; Hackney 1992; Hamilton, Gibson 1996; Merrow 1988; Dumont et al. 1997).

The results of previous studies indicated a correlation between requirements definition and management (RDM) effort and project performance. Additionally, a review of the literature suggests that RDM effort may improve requirements quality in terms of correctness, consistency, and completeness, which subsequently affecting the performance of a project (Damian, Chisan 2006; Procaccino et al. 2002; Brooks 1987; Kauppinen et al. 2004; Herbsleb, Goldenson 1996; Radujković et al. 2010; Huang, Hsueh 2010; Toor, Ogunlana 2010). This study extends previous studies by addressing the impact of requirements completeness on project performance in the building industry. Based on the relevant literature, the following hypothesis was postulated and tested:

$\mathrm{H}$ : Requirements completeness positively influences building project performance.

While the diverse benefits of preproject planning have received substantial attention, the number of studies dealing with the importance of project requirements is rather scarce. This research adds to the literature in two valuable ways. First, it develops a comprehensive framework for evaluating key project requirements in the building sector. Second, it offers important results on prioritization of building project requirements and their impacts on project success.

\section{Phase 1 research}

This research was divided into four phases (see Figure 1). Phase 1 included determining the applicability of the proposed project requirements. A survey was developed to investigate the degree, if any, to which the proposed requirements apply to building projects. The survey was designed to include requirements that were thought to have substantial impact on building projects. The listing

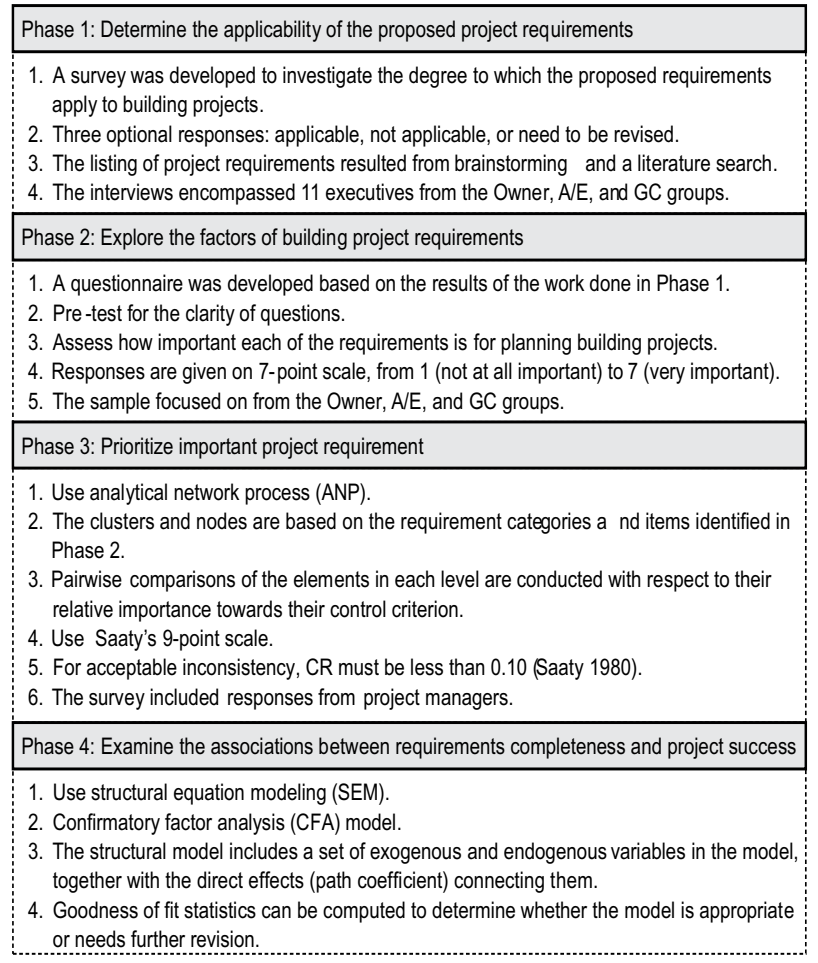

Fig. 1. Research methodology

of project requirements, which resulted from both brainstorming and a literature search (Dumont et al. 1997; Cho, Gibson 2001), contained over 100 items. Therefore, a systematic method for eliminating some of the less important requirements was developed. Each requirement was then tested to ensure it applies to building projects. As such, identification of the requirements was based on previous studies and interviews with construction practitioners. The industry interviews encompassed 11 executives from the Owner, Architect/Engineering (A/E), and General Contractor (GC) groups. Each of the professionals has over 20 years of senior management experience in the industry. For each proposed project requirements, the survey asked the participants to assess the extent to which individual requirements apply to projects in the building sector. This survey offered respondents three optional responses: applicable, not applicable, or need to be revised. The survey allowed the participants to offer additional comments on a potential revision. The refined assessment items were included in the Phase 2 survey questionnaire. Finally, the Phase 2 survey makes use of 81 project requirements in assessing their relative importance.

\section{Phase 2 research}

\subsection{Procedure}

Phase 2 of the research entailed exploring the factors of building project requirements. In other words, the purpose of Phase 2 was to determine key requirement categories and items. A questionnaire was developed based on the results of the work done in Phase 1. As such, the 
81 project requirements identified in Phase 1 were included in the Phase 2 questionnaire. Additionally, copies of a draft survey were sent to several industry professions to pre-test for the clarity of questions. Their insights were also incorporated into the final version of the survey questionnaire. The questionnaire was used to assess how important each of the requirements is for planning building projects. Responses are given on 7-point scale, from 1 (not at all important) to 7 (very important).

This research employed survey methodology for Phase 2 data collection. The survey instrument was used to measure the relative importance of building project requirements from the viewpoints of major stakeholders involved in projects. Thus, the sample for Phase 2 research focused on the Owner, Architect/Engineering, and General Contractor groups in the Taiwanese building industry. Individuals interested in participating in this phase were identified by a search from a number of industry associations. The Owner' sample was selected from various public and private owners. In addition, the A/E's sample was selected from the National Association of Architect, Taiwan and Chinese Association of Engineering Consultants. On the other hand, the sample of GC was drawn from members of General Contractors Association, Taiwan. The survey questionnaire was sent to more than 800 senior practitioners on June 30, 2008. Some of the organizations were then contacted via phone or email to identify the manager or the person involving in building projects by name and title. Reminders were sent by e-mail or phone after survey mailing. The initial mailing elicited 89 usable responses. Finally, four weeks after the initial mailing, a second mailing of the survey was made to non-respondents. A reminder letter, too, followed the second mailing. An additional 46 usable responses were returned. In summary, of the 811 questionnaires sent, 137 were returned. The overall response rate was 17.12 percent. Among the returned surveys, 2 were discarded since they contained too many missing values. Ultimately, 135 survey responses were used in the analysis.

\subsection{Participants and data analysis}

The sample was composed of 39 practitioners from the Owner group. With respect to years of experience, 17.95 percent of the respondents are more than $20,12.82$ percent are between 16 and 20, 25.64 percent are between 11 and 15, 23.08 percent are between 6 and 10, and the remaining 20.51 are less than 6. Furthermore, 35.90 percent of the respondents indicated that they held a Master's degree, while another 28.21 percent held a Bachelor's degree. The remaining 35.90 percent held an associate's degree. The sample consisted of 62 practitioners from the Architect/Engineering group. With respect to years of experience, 23.73 percent of the respondents are more than 20, 13.56 percent are between 16 and 20, 32.20 percent are between 11 and 15, 20.34 percent are between 6 and 10, and the remaining 10.17 are less than 6. Furthermore, 57.63 percent of the respondents indicat- ed that they held a Master's degree, while 42.37 percent held a Bachelor's degree. Additionally, the sample also included 34 professionals from the General Contractor group. With respect to education, 30.30 percent of the respondents indicated that they held a Master's degree, while another 45.45 percent held a Bachelor's degree. The remaining 24.24 percent held an associate's degree. The sample was randomly selected from the population. Based on sampling frame (i.e. a list of all those within a population who can be sampled) provided by the industry associations, the structure of the population is similar to that of the sample.

After data are collected, a preliminary data analysis was conducted. Factor analysis was employed to reduce the building project requirements into several factors. The items associated with these key factors were selected to assess requirements quality in Phase 3.

\section{Phase 3 research}

\subsection{ANP decision model}

To address the issue regarding prioritization of project requirements, this research employed the analytic network process as a suitable multicriteria decision analysis tool. The ANP technique is a general form of the analytic hierarchy process (AHP) (Saaty 1996). AHP is one of the most commonly used multicriteria decision analysis tools. This approach requires a hierarchic structure where criteria are mutually independent. However, evaluation criteria could be interdependent to each other. ANP was shown to be effective in addressing such complexity of interactions in the structure.

The ANP model includes all contributive factors (clusters and nodes) and their possible direct interactions in the decision structure. The clusters and nodes used in the model are based on the requirement categories and items identified in Phase 2.

\subsection{Processing procedures and data gathering}

In the ANP model, pairwise comparisons of the elements in each level are conducted with respect to their relative importance towards their control criterion (Saaty 1996). As such, with respect to any criterion, pairwise comparisons are performed in two levels (i.e. the element level and the cluster level comparison). The intensity assigned to the comparison process between factors was made using Saaty's 9-point scale. Saaty (1988) has suggested a scale of 1 to 9 when comparing two components, with a score of 1 representing indifference between the two components and 9 being overwhelming dominance of the component under consideration over the comparison component. After all pairwise comparisons were completed, the priority weight vector was computed. In addition, the inconsistency of judgments was checked using the consistency ratio (CR). For acceptable inconsistency, CR must be less than 0.10 (Saaty 1980). The column vectors from the limit matrix were also normalized accord- 
ing to clusters to provide the overall priorities. Group assessment was integrated using geometric mean (Saaty 1980). Finally, the priority of the building project requirements was identified. The calculations were implemented through the software Superdecisions.

Since evaluation criteria could be interdependent to each other in the ANP model, the respondents should have a view of the project that crossed functional boundaries and organizational levels and understand the interdependency among the project requirements. Thus, only project managers involved in the project from start to end are qualified to participate in the study. The qualifications assured that respondents understand the relationships among the criteria investigated in the survey. The survey included responses from 18 project managers in the building industry. The sample size is adequate for ANP/AHP analysis (Tseng et al. 2011; Vidal et al. 2011; Mahdi, Alreshaid 2005). With respect to years of experience, all of the respondents had more than 10 years of experience in the building industry.

Kendall's $W$ was used for assessing agreement among the 18 raters. The Kendall's W coefficient is 0.76 , which indicates a fair degree of agreement. A coefficient of unity (i.e. 1.0) signifies perfect agreement, and a coefficient greater than 0.70 represents strong agreement (Okoli, Pawlowski 2004; Schmidt 1977). Thus, the results show significant agreement among these respondents.

\section{Phase 4 research}

\subsection{Survey process and structure}

The primary objective of this research was to develop a comprehensive framework for evaluating key building project requirements. The second objective was to identify and prioritize important project requirement using the analytical network process (ANP). The two objectives are associated with the scope of research in Phase 2 and Phase 3. After identifying the "key" requirement categories and items, Phase 4 of the research employed structural equation modeling (SEM) analysis to examine the associations between completeness of the "important" requirements identified in Phases 2 and 3 and project success. Thus, the third research objective pertains to the scope of research in Phase 4. A data collection tool was used to assess the relationships. The survey instrument was used to measure levels of requirements completeness and the performance of building projects. The data collection tool was developed based on the items used in Phase 3 research and variables used in previous studies. The survey was composed of three sections: 1) levels of requirements definition; 2) project performance; and 3) project and personal information. The first section measured completeness of project requirements. The items in the ANP model were employed to investigate requirement completeness on the subjective project. In other words, this section evaluated levels of completeness of the requirements used in the ANP model. In addition, the second section investigated overall project performance.
Finally, the third section obtained information concerning the project and the respondent. Hypotheses were developed and tested to determine the statistical significance of the hypothetical relationships.

\subsection{Sample selection and data collection}

An industry-wide survey of requirements definition effort and performance on building projects was conducted in Taiwan between March 2009 and February 2010. In order to obtain an adequate sample for structural equation modeling analysis, More data were collected between October and December 2011. The data collection tool was developed to collect project-based data. Project responses were collected through personal interviews. Individuals interested in participating in this phase were identified by a search from various industry associations. In order to obtain a truly representative sample, not only was the geographic mix of projects intentionally diverse, but a diverse mix of participation was sought with respect to project size. Additionally, a specified mix of team size was targeted in order to obtain a representative sample of the industry. More than 200 projects were investigated and some were not included in the analysis because they contained insufficient information. In addition, the projects were examined to ensure that no duplicate project information was collected. Ultimately, 208 survey responses were used in the analysis. Table 1 presents characteristics of sampled projects.

The sample's respondents consisted of project managers, project directors, project planners, and project superintendents. With respect to years of experience, 7.7 percent are more than 20,19.7 percent are between 16 and 20, 21.6 percent are between 11 and 15, 33.2 percent are between 5 and 10 , and the remaining 17.8 percent are less than 5. Additionally, 4.8 percent of the respondents indicated that they held a Master's degree, while another 45.7 percent held a Bachelor's degree. Additionally, 41.8 percent of the respondents indicated that they held associate's degree. The remaining 6.7 percent held a high school diploma.

\subsection{Variable measurement and index development}

As previously discussed, completeness of project requirements was evaluated based on the items selected from the ANP model. Respondents were asked to indicate how successful their projects have been in achieving completeness for each item. A six-point scale was utilized with $1=$ not at all successful and $6=$ extremely successful. Based on Cho and Gibson (2001) and Dumont et al. (1997), a detailed definition of the requirements is presented in Appendix A.

On the other hand, questions from Müller and Turner (2007), Pinto and Slevin (1988), Larson and Gobeli (1988), Keller (1994), Freeman and Beale (1992), Shenhar et al. (1997), and Westerveld (2003) were adapted to measure building project performance. Each item was rated on a 6-point scale, where 1 represented strongly disagree and 6 represented strongly agree. 
Table 1. Characteristics of sampled projects

\begin{tabular}{|c|c|c|c|}
\hline Characteristic & Class & Number & $\begin{array}{l}\text { Percent of } \\
\text { projects }\end{array}$ \\
\hline Initial site & $\begin{array}{l}\text { Greenfield } \\
\text { (or new) }\end{array}$ & 176 & 84.6 \\
\hline Initial site & Renovation & 12 & 5.8 \\
\hline Initial site & Expansion & 20 & 9.6 \\
\hline Project size & $<\$ 5$ Million & 87 & 41.8 \\
\hline Project size & $\$ 5-20$ Million & 67 & 32.2 \\
\hline Project size & $>\$ 20$ Million & 46 & 22.1 \\
\hline Project size & Not available & 8 & 3.8 \\
\hline Project duration & Short & 69 & 33.2 \\
\hline Project duration & Medium & 73 & 35.1 \\
\hline Project duration & Long & 58 & 27.9 \\
\hline Project duration & Not available & 8 & 3.8 \\
\hline $\begin{array}{l}\text { Number of core } \\
\text { team member }\end{array}$ & $<10$ & 130 & 62.5 \\
\hline $\begin{array}{l}\text { Number of core } \\
\text { team member }\end{array}$ & $10-20$ & 28 & 13.5 \\
\hline $\begin{array}{l}\text { Number of core } \\
\text { team member }\end{array}$ & $>20$ & 32 & 15.4 \\
\hline $\begin{array}{l}\text { Number of core } \\
\text { team member }\end{array}$ & Not available & 18 & 8.7 \\
\hline Project typicality & Traditional & 167 & 80.3 \\
\hline Project typicality & Advanced & 37 & 17.8 \\
\hline Project typicality & Not available & 4 & 1.9 \\
\hline Owner regulation & Private & 125 & 60.1 \\
\hline Owner regulation & Public & 79 & 38.0 \\
\hline Owner regulation & Not available & 4 & 1.9 \\
\hline Complexity & Low & 46 & 22.1 \\
\hline Complexity & Medium & 127 & 61.1 \\
\hline Complexity & High & 33 & 15.9 \\
\hline Complexity & Not available & 2 & 1.0 \\
\hline
\end{tabular}

\subsection{Dealing with validity and reliability}

The content validity of the survey used in Phase 4 was tested through a literature review and interviews with practitioners. In other words, the survey items were based on previous studies and discussions with these industry executives. The industry interviews encompassed nine construction industry executives. A specified group involvement was also targeted in order to acquire a comprehensive knowledge from different perspectives. The industry interviews encompassed nine executives from the Owner, $\mathrm{A} / \mathrm{E}$, and $\mathrm{GC}$ groups (three practitioners from each group). Each of the professionals has over 20 years of senior management experience in the industry. The refined assessment items were included in the final survey. Finally, copies of a draft survey were sent to several industry professions to pre-test for the clarity of questions. Their insights were also incorporated into the final version of the survey. The construct validity was tested by factor analysis. Factors were extracted using Varimax rotation. As suggested by Hair et al. (1995), an item is considered to load on a given factor if the factor loading from the rotated factor pattern is 0.50 or more for that factor. Cronbach's coefficient $(\alpha)$ was also computed to test the reliability and internal consistency of the responses. The values of Cronbach's $\alpha$ above 0.7 are considered acceptable and those above 0.8 are considered meritorious (Nunnally 1978; Carmines, Zeller 1979; Litwin 1995).

\section{Results and Analysis}

\subsection{Identification of key project requirement categories and items}

In Phase 2 of this study, factor analysis with Varimax rotation was used to identify key requirement factors. Eigenvalue greater than one was used to determine the number of factors in the data set (Churchill 1991). Only variables with a factor loading greater than 0.5 were extracted (Hair et al. 1995). Figure 2 presents the scree plot. The 81 items of project requirements investigated are classified into six factors. In other words, the results indicated that six factors were found to underlie the various sets of project requirements in the building sector. Twenty-four items were dropped due to low factor loading. Additionally, the factor loadings for the other items range from 0.505 to 0.804 . The six constructs categorized are project design parameter, project plan, site information, project control, project strategy, and building programming.

Cronbach's coefficient $(\alpha)$ was computed to test the reliability and internal consistency of the responses. Reliability was assessed for project design parameter at 0.962 , project plan at 0.935 , site information at 0.944 , project control at 0.913 , project strategy at 0.862 , and building programming at 0.870 . In addition, the relative importance for the survey items is presented in Table 2 .

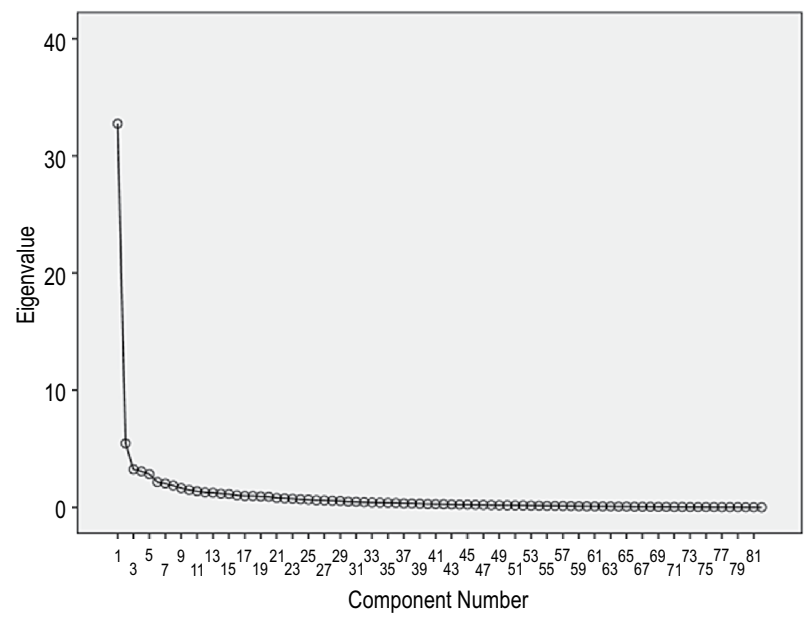

Fig. 2. Scree plot 
Table 2. Relative importance of project requirements for the categories

\begin{tabular}{|c|c|c|c|c|c|}
\hline Factor & Project requirement & Mean & Factor & Project requirement & Mean \\
\hline 1 & Structural requirements & 6.19 & 3 & Safety procedures & 5.63 \\
\hline 1 & Structural design & 5.94 & 3 & Reliability philosophy & 5.57 \\
\hline 1 & Architectural design & 5.90 & 3 & Maintenance philosophy & 5.47 \\
\hline 1 & Site survey & 5.83 & 3 & Training requirements & 5.47 \\
\hline 1 & Electrical and mechanical design & 5.82 & 3 & Operating philosophy & 5.46 \\
\hline 1 & Piping system requirements & 5.82 & 3 & Waste treatment requirements & 5.44 \\
\hline 1 & Construction process & 5.77 & 3 & Water treatment requirements & 5.34 \\
\hline 1 & Civil design & 5.74 & 3 & Soil tests & 5.32 \\
\hline 1 & Utility sources with supply conditions & 5.71 & 3 & Transportation requirements & 5.21 \\
\hline 1 & Site layout & 5.67 & 4 & Project schedule control & 6.20 \\
\hline 1 & Geotechnical information & 5.59 & 4 & Project cost control & 6.19 \\
\hline 1 & Civil information & 5.50 & 4 & Project cost estimate & 6.07 \\
\hline 1 & Evaluation of existing facilities & 5.50 & 4 & Overview of work scope & 6.03 \\
\hline 1 & Plot plan & 5.29 & 4 & Project control requirements & 6.01 \\
\hline 2 & Owner approval requirements & 5.93 & 4 & Project schedule estimate & 5.89 \\
\hline 2 & Design plan and approval & 5.80 & 4 & Project management strategy & 5.58 \\
\hline 2 & Project design criteria & 5.77 & 5 & Human resource management & 5.53 \\
\hline 2 & Evaluation of adjacent building & 5.76 & 5 & Economic analysis & 5.45 \\
\hline 2 & Purpose of building use & 5.74 & 5 & Project strategy & 5.30 \\
\hline 2 & Construction plan and approval & 5.60 & 5 & Alternatives considerations & 5.27 \\
\hline 2 & Building use planning & 5.59 & 5 & Value-analysis process & 5.13 \\
\hline 2 & Site location & 5.58 & 5 & Marketing strategy & 5.01 \\
\hline 2 & Space evaluation & 5.53 & 6 & Identify materials & 5.89 \\
\hline 2 & Facility requirements & 5.52 & 6 & Indoor rooms & 5.40 \\
\hline 2 & Project objective statement & 5.29 & 6 & Open space requirements & 5.35 \\
\hline 2 & Future expansion considerations & 5.24 & 6 & Windows and doors & 5.34 \\
\hline 3 & Fire protection & 5.94 & 6 & Compartment requirements & 5.29 \\
\hline 3 & Site life safety considerations & 5.82 & 6 & Painting requirements & 5.01 \\
\hline 3 & Safety management & 5.77 & 6 & Storage space & 4.94 \\
\hline
\end{tabular}

Note: Responses are given on 7-point scale, from 1 (not at all important) to 7 (very important)

\subsection{Factor structure of project performance}

Factor analysis was also used to decide the grouping of project success. The items of project performance construct are classified into four factors. The subscales are schedule success, cost success, quality performance, and overall benefit. Reliability was assessed for schedule success at 0.914 , cost success at 0.920 , quality performance at 0.944 , and overall benefit at 0.918 . All of the $\alpha$ values for the sub-dimensions are above 0.9 , indicating a high level of internal consistency among the project performance items.

\subsection{Decision model}

The listing of project requirements, which resulted from factor analysis in Phase 2, contained 58 items (see Table 2). This list was too long to allow respondents to complete the ANP survey in a reasonable amount of time. Therefore, the five most important project requirements for each of the six requirement categories were selected for further
ANP analysis. Finally, the data collection tool makes use of 30 project requirement items in assessing prioritization.

The factors and items identified in Phase 2 were used to develop a model that explicitly considers many of the important project requirement found in literature and practice. This model was then used to prioritize the project requirements. The structure used in this model is presented in Figure 3. In other words, Figure 3 lists the 30 key project requirements used in the ANP model. The relevant criteria are structured in the form of a hierarchy. "Successful project performance" was placed on the top of the hierarchy used for the ANP model. In this model, the first level below the goal is the requirement categories: project design parameter, project plan, site information, project control, project strategy, and building programming. The topmost elements (requirement categories) are decomposed into subcomponents (requirement items). As shown in Figure 3, criteria could be interdependent to each other for the category level and the item level. 


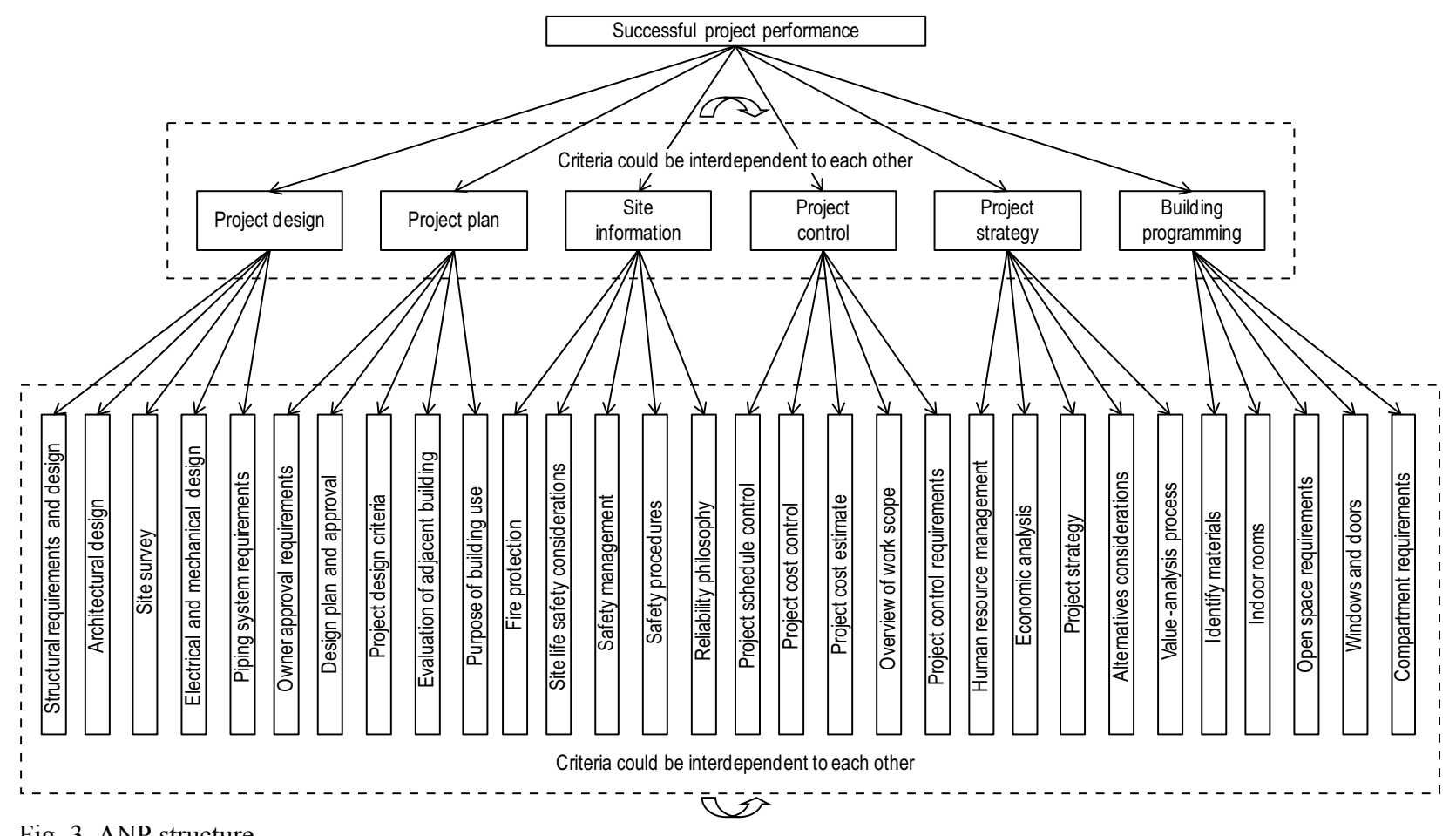

Fig. 3. ANP structure

\subsection{Prioritization based on ANP model}

In analyzing the prioritization by using the ANP approach, the priorities of the requirement categories and items were determined. Table 3 shows the global priorities of the 30 criteria derived by taking the limit of weighted supermatrix of the ANP model. The priorities of the requirement categories in the model are also reported in Table 3. For the category level, the two most important requirement categories in the building sector were building programming and site information. For the item level, five building project requirements (weights were over 0.05 ) stood out as being very important from the perspectives of project managers: compartment requirements, reliability philosophy, open space requirements, indoor rooms, and human resource management.

\subsection{Impacts of requirement completeness on project success}

Structural equation model (SEM) analysis was used to examine the impact of requirement completeness on project performance. Two main components are included in SEM: measurement model and structural model. Prior to estimating the structural model, a confirmatory factor analysis was conducted to verify the measurement model (Anderson, Gerbing 1988). Multiple fit criteria were used to assess the overall fit of the model (Bollen, Long 1993; Hair et al. 1995). In the proposed model, "requirement completeness" and "project performance" are a second order construct. For example, "project performance" is considered to be a four-dimensional construct composed of schedule success, cost success, quality performance, and overall benefit. In other words, the latent variable (project performance) is represented by four latent vari- ables. The second order approach was used to maximize the interpretability of both the measurement and the structural models (Hair et al. 1995). The data were analyzed using the AMOS/SPSS statistical package. The model refinement was performed to improve the fit to its recommended levels as shown in Table 4. Based on several trials resulting in elimination of some of the items, all of the scales met the recommended levels. Furthermore, the composite reliability for all constructs was above the 0.7 level suggested by Nunnally (1978), indicating adequate reliability for each construct. Thus, the results provide evidence that the scales are reliable (see Table 4).

All of the factor loadings are statistically significant at the five percent level and exceed the arbitrary 0.5 standard (Fornell, Larcker 1981). In addition, all constructs have an average variance extracted (AVE) greater than 0.5 . Thus, these constructs demonstrate adequate convergent validity. Discriminant validity evaluates whether the constructs are measuring different concepts (Hair et al. 2006). The discriminant validity of each constructs was assessed. First, a procedure recommended by Bagozzi et al. (1991) was adopted. Each set of construct measures was paired with another set of measures. Each model was run twice, once by constraining the correlations between the two constructs to unity and once by freeing this parameter (Li, Cavusgil 2000), then a chi-square difference test was conducted. The results show that the chi-square values are significantly lower for the unstrained models at the five percent level, which suggests that the constructs exhibit discriminant validity.

Figure 4 presents results of the overall model fit in the structural model. A feasible model was selected based on the recommended Goodness-Of-Fit (GOF) measures and the model that satisfies both theoretical expectations 
Table 3. Criteria in the ANP model

\begin{tabular}{|c|c|c|c|c|}
\hline Category & Weight & Item & Weight & Ranking \\
\hline Project design parameter & 0.073 & Structural requirements and design & 0.020 & 23 \\
\hline Project design parameter & 0.073 & Architectural design & 0.013 & 28 \\
\hline Project design parameter & 0.073 & Site survey & 0.012 & 30 \\
\hline Project design parameter & 0.073 & Electrical and mechanical design & 0.018 & 26 \\
\hline Project design parameter & 0.073 & Piping system requirements & 0.017 & 27 \\
\hline Project plan & 0.116 & Owner approval requirements & 0.020 & 25 \\
\hline Project plan & 0.116 & Design plan and approval & 0.032 & 15 \\
\hline Project plan & 0.116 & Project design criteria & 0.041 & 8 \\
\hline Project plan & 0.116 & Evaluation of adjacent building & 0.037 & 10 \\
\hline Project plan & 0.116 & Purpose of building use & 0.041 & 7 \\
\hline Site information & 0.227 & Fire protection & 0.026 & 21 \\
\hline Site information & 0.227 & Site life safety considerations & 0.035 & 12 \\
\hline Site information & 0.227 & Safety management & 0.012 & 29 \\
\hline Site information & 0.227 & Safety procedures & 0.024 & 22 \\
\hline Site information & 0.227 & Reliability philosophy & 0.061 & 2 \\
\hline Project control & 0.157 & Project schedule control & 0.033 & 14 \\
\hline Project control & 0.157 & Project cost control & 0.041 & 9 \\
\hline Project control & 0.157 & Project cost estimate & 0.027 & 20 \\
\hline Project control & 0.157 & Overview of work scope & 0.020 & 24 \\
\hline Project control & 0.157 & Project control requirements & 0.029 & 17 \\
\hline Project strategy & 0.158 & Human resource management & 0.054 & 5 \\
\hline Project strategy & 0.158 & Economic analysis & 0.034 & 13 \\
\hline Project strategy & 0.158 & Project strategy & 0.032 & 16 \\
\hline Project strategy & 0.158 & Alternatives considerations & 0.029 & 18 \\
\hline Project strategy & 0.158 & Value-analysis process & 0.036 & 11 \\
\hline Building programming & 0.268 & Identify materials & 0.028 & 19 \\
\hline Building programming & 0.268 & Indoor rooms & 0.054 & 4 \\
\hline Building programming & 0.268 & Open space requirements & 0.061 & 3 \\
\hline Building programming & 0.268 & Windows and doors & 0.050 & 6 \\
\hline Building programming & 0.268 & Compartment requirements & 0.062 & 1 \\
\hline
\end{tabular}

Table 4. Properties of the main constructs

\begin{tabular}{lccccccc}
\hline \multicolumn{1}{c}{ Metric } & $\begin{array}{c}\text { Composite } \\
\text { reliability }\end{array}$ & $\begin{array}{c}\text { GFI } \\
(>0.90 \text { desired })\end{array}$ & $\begin{array}{c}\text { AGFI } \\
(>0.80 \text { desired })\end{array}$ & $\begin{array}{c}\text { CFI } \\
(>0.90 \text { desired })\end{array}$ & $\begin{array}{c}\text { NFI } \\
(>0.90 \text { desired })\end{array}$ & $\begin{array}{c}\text { RMSEA } \\
(<0.08 \text { desired })\end{array}$ \\
\hline Requirement completeness & 0.898 & 0.902 & 0.858 & 0.973 & 0.923 & 0.050 \\
\hline Project performance & 0.924 & 0.904 & 0.850 & 0.967 & 0.943 & 0.078 \\
\hline
\end{tabular}

and GOF was finally selected for structural equation modeling analysis (Molenaar et al. 2000). The overall fit statistics indicated a very good fit for the model. The chi-square statistic for the full measurement model was nonsignificant $(\mathrm{p}>0.05)$ indicating a good fit between the data and the proposed model. The normed fit index (NFI), comparative fit index (CFI), and goodness of fit index (GFI), with values of $0.931,0.951$, and 0.909 respectively, were all above the recommended acceptable 0.90 level (Chau 1997). In addition, the adjusted goodness of fit index $(\mathrm{AGFI}=0.852)$ was above the $0.80 \mathrm{~min}$ - imum recommended value. Finally, the root mean square error of approximation (RMSEA) was 0.076, which was below the cut-off level of 0.08 recommended by Browne and Cudeck (1993).

The test of the hypothesis was based on the direct effects (structural coefficients) among the constructs as shown in Figure 4. The hypothesis proposed a positive relationship between requirement completeness and project performance. This hypothesis was supported since the standardized coefficient was 0.73 and statistically significant $(\mathrm{p}<0.001)$. 


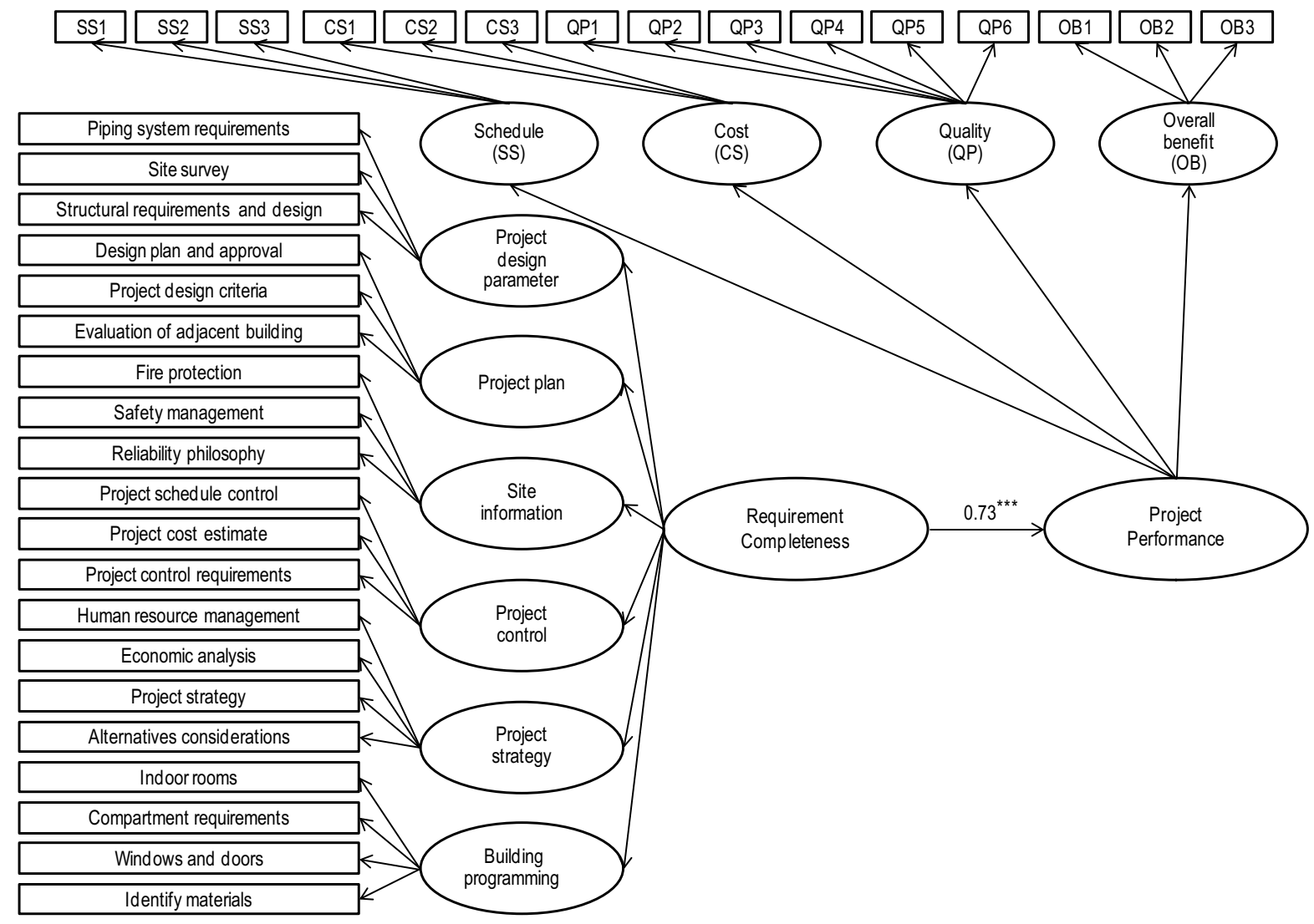

Fig. 4. Research model estimation results

\section{Conclusion and discussions}

While the diverse benefits of preproject planning have received substantial attention, the number of studies dealing with prioritization of project requirements is rather scarce. The research results offer guides to project planning process in the building sector. Findings from this study are helpful to project planners in identifying relative importance of building project requirements. Project managers can use the research results to modify their current building project planning. The findings show that building programming and site information have a higher priority in requirement definition than project control, project strategy, and project design parameter. Building programming and site information are associated with fundamental project requirements. Many other project requirements are dependent on the two categories of requirements. This may explain why building programming and site information are more important than the other requirement categories and why the ranking of the requirements evaluated in Phase 2 (criteria are mutually independent) and Phase 3 (criteria could be interdependent to each other) is different. Among the sub-criteria, the five building project requirements project managers considered most important were compartment requirements, reliability philosophy, open space requirements, indoor rooms, and human resource management. This indicates that project planners need to be especially aware of the importance of these project requirements during the plan- ning of a project. The findings also indicate that requirement completeness contributes significantly to building project success.

The results suggest that the two most important requirement categories were building programming and site information. With respect to building programming, project managers must clearly define compartment requirements, windows and doors, identify materials, and indoor rooms, which contribute significantly to building project success. Regarding site information, reliability philosophy and site life safety considerations are very important requirements. Project design criteria, project schedule control, project cost estimate, and human resource management are also critical requirements that have impacts on building project success. Project planners should prompt different departments to cooperate in requirements definition and exchange information so that each group is aware of the needs and resources of the other. Additionally, offering team members with education is also an important method to improve requirements definition and management. Project managers should also deal properly with the conflicts between different groups and encourage communication to eliminate disagreement. They must promote trust between different departments and educate team members to consider different perspectives.

This study has certian implications with respect to requirements definition and management (RDM) practice. Project managers should develop a complete re- 
quirements definition and management process to manage building project requirements. They need to define a flexible requirements definition and management process and integrate the process with the project planning process. More importantly, they must involve the owner group in improvement work. Training and continuous improvement is also critical to requirements definition and management implementation. Project managers should set goals for requirements definition and management process improvement and conduct an evolutionary improvement strategy. Testing the requirements definition and management process in a pilot project is also important for building project planning. In addition, they must measure the impact of the requirements definition and management improvement efforts on building project performance. Finally, they should conduct just-in-time training to get project teams to apply the requirements definition and management process in practice. On the other hand, project managers must also pay attention to requirements quality and stability. They should use a particular method to gather project requirements and adopt requirements definition and management practice to make sure the requirements are complete and accurate. Improvements in consistency, verifiability, prioritization, and ambiguity elimination are also important issues for building project planning. Project managers must also engage in practices that control changes in project scope and owner requirements.

The paper provides value to practitioners by providing a general model for project requirement evaluation and to researchers by demonstrating a new application of ANP. This strategic decision making tool assisted the project planners in development of project requirements. Although the decision levels involved in any particular project may be different depending on the activities involved, the ANP model presented is a general model applicable to most building projects. In addition, the basic framework in this model can be adapted to a particular situation. Project managers may select a set of criteria which are important for a particular project. In other words, a criterion that a project manager considers to be critical may be added to the general model. On the other hand, the model did not consider all possible criteria. As discussed previously, the listing of project requirements, which resulted from factor analysis, was too long to allow respondents to complete the ANP survey in a reasonable amount of time. Therefore, a systematic method for eliminating some of the less important project requirements was developed. Depending on the project environment, additional criteria could also be added. Additionally, the weighting given each criterion in the ANP model may be dependent on the particular situation of a proect.

The research results offer guides to project planning process. Findings from this study are helpful to project planners in deciding what priority each project requirement has in the building sector. Project planners can use the research results to understand the associations be- tween requirement completeness and project success and modify their current project planning. While the model presented provides value, there are issues for future validation. Future research may also develop different models to validate and compare their efficacy. In addition, case studies may be conducted to validate the models and determine which project alternatives would best meet the company's goals. Another objective for future study is to develop requirement evaluation models and investigate the prioritization of project requirements for the other sectors (industrial or infrastructure projects). Finally, Delphi approach can be used to achieve consensus of opinion in the preference weightings.

\section{References}

Ahmed, S. M.; Sang, L. P.; Torbica, Z. M. 2003. Use of quality function deployment in civil engineering capital project planning, Journal of Construction Engineering and Management 129(4): 358-368.

http://dx.doi.org/10.1061/(ASCE)0733-9364(2003)129:4(358)

Anderson, J.; Gerbing, D. 1988. Structural equation modelling in practice: a review and recommended two-step approach, Psychological Bulletin 103(2): 411-423. http://dx.doi.org/10.1037/0033-2909.103.3.411

Artto, K.; Kujala, J.; Dietrich, P.; Martinsuo, M. 2008. What is project strategy?, International Journal of Project Management 26(1): 4-12. http://dx.doi.org/10.1016/j.ijproman.2007.07.006

Bagozzi, R. P.; Yi, Y.; Phillips, L. W. 1991. Assessing construct validity in organizational research, Administrative Science Quarterly 36(3): 421-458. http://dx.doi.org/10.2307/2393203

Bollen, K.; Long, J. 1993. Testing structural equation models. Newbury Park, California: Sage Publications.

Brooks, Jr. F. P. 1987. No silver bullet: essence and accidents of software engineering, IEEE Computer Society Press 20(4): 10-19. http://dx.doi.org/10.1109/MC.1987.1663532

Browne, M. W.; Cudeck, R. 1993. Alternative ways of assessing model fit. Newbury Park, California: Sage Publications.

Carmines, E. G.; Zeller, R. A. 1979. Reliability and validity assessment. California: Sage Publication.

Chau, P. 1997. Re-examining a model for evaluating information center success using a structural equation modelling approach, Decision Sciences 28(2): 309-334. http://dx.doi.org/10.1111/j.1540-5915.1997.tb01313.x

Cho, C. S.; Furman, J. C.; Gibson, G. E. 1999. Development of the project definition rating index (PDRI) for building projects. Research Report 155-11. Texas: University of Texas at Austin.

http://dx.doi.org/10.1061/(ASCE)1076-0431(2001)7:4(115)

Cho, C. S.; Gibson, G. E. 2001. Building project scope definition using project definition rating index, Journal of Architectural Engineering 7(4): 115-125.

Churchill, G. A. 1991. Marketing research: methodological foundation. $5^{\text {th }}$ ed. New York: The Dryden Press.

Construction Industry Institute (CII) 1995. Pre-project planning handbook. Special publication 39-2. Texas: Construction Industry Institute.

Damian, D.; Chisan, J. 2006. An empirical study of the complex relationships between requirements engineering, IEEE Transactions on Software Engineering 32(7): 433453. http://dx.doi.org/10.1109/TSE.2006.61

Dumont, P. R.; Gibson, G. E.; Fish, J. R. 1997. Scope management using project definition rating index, Journal of Management in Engineering 13(5): 54-60.

http://dx.doi.org/10.1061/(ASCE)0742-597X(1997)13:5(54) 
Fornell, C.; Larcker, D. F. 1981. Evaluating structural equation models with unobservable variables and measurement error, Journal of Marketing Research 18(1): 39-50. http://dx.doi.org/10.2307/3151312

Freeman, M.; Beale, P. 1992. Measuring project success, Project Management Journal 23(1): 8-17.

Gibson, G. E.; Kaczmarowski, J. H.; Lore, H. E. 1995. Preproject-planning process for capital facilities, Journal of Construction Engineering and Management 121(3): 312-318.

http://dx.doi.org/10.1061/(ASCE)0733-9364(1995)121:3(312)

Gibson, G. E.; Liao, S.; Broaddus, J. A.; Bruns, T. A. 1997. The University of Texas System capital project performance, 1990-1995. OFPC Paper 97-1, Texas: University of Texas System.

Gidado, K. 2004. Enhancing the prime contractor's pre-construction planning, Journal of Construction Research 5(1): 87-106. http://dx.doi.org/10.1142/S1609945104000073

Görög, M. 2009. A comprehensive model for planning and controlling contractor cash-flow, International Journal of Project Management 27(5): 481-492. http://dx.doi.org/10.1016/j.ijproman.2008.08.001

Griffith, A. F.; Gibson, G. E. 2001. Alignment during preproject planning, Journal of Management in Engineering 17(2): 69-76.

http://dx.doi.org/10.1061/(ASCE)0742-597X(2001)17:2(69) Griffith, A. F.; Gibson, G. E.; Hamilton, M. R.; Tortora, A. L.; Wilson, C. T. 1999. Project success index for capital facility construction projects, Journal of Performance of Constructed Facilities 13(1): 39-45.

http://dx.doi.org/10.1061/(ASCE)0887-3828(1999)13:1(39)

Griffith, A. F.; Gibson, G.. E. 1995. Project communication and alignment during pre-project planning, in Proceedings of PMI '95 Conference, 13-19 October, New Orleans, Louisiana, 76-83.

Hackney, J. W. 1992. Control and management of capital projects. $2^{\text {nd }}$ ed. New York: McGraw-Hill.

Hair, J. F.; Anderson, R. E.; Tatham, R. L.; Black, W. C. 1995. Multivariate data analysis with readings. $4^{\text {th }}$ ed. New Jersey: Prentice Hall International.

Hair, J. F.; Black, W. C.; Babin, B. J.; Anderson, R. E.; Tatham, R. L. 2006. Multivariate data analysis. $6^{\text {th }}$ ed. Upper Saddle River, New Jersey: Prentice-Hall.

Hamilton, M. R.; Gibson, G. E. 1996. Benchmarking preproject planning effort, Journal of Management in Engineering 12(2): 25-33.

http://dx.doi.org/10.1061/(ASCE)0742-597X(1996)12:2(25)

Handa, V.; Adas, A. 1996. Predicting the level of organizational effectiveness: a methodology for the construction firm, Construction Management and Economics 14(4): 341-352. http://dx.doi.org/10.1080/014461996373412

Hanna, A. S.; Skiffington, M. A. 2010. Effect of preconstruction planning effort on sheet metal project performance, Journal of Construction Engineering and Management 136(2): 235-241.

http://dx.doi.org/10.1061/(ASCE)0733-9364(2010)136:2(235)

Heesom, D.; Mahdjoubi, L. 2004. Trends of 4D CAD applications for construction planning, Construction Management and Economics 22(2): 171-182. http://dx.doi.org/10.1080/0144619042000201376

Herbsleb, J. D.; Goldenson, D. R. 1996. A systematic survey of CMM experience and results, in Proceedings of the $18^{\text {th }}$ International Conference on Software Engineering, 25-30 March, Berlin, Germany, 323-330.

Huang, C.; Hsueh, S. 2010. Customer behavior and decision making in the refurbishment industry - a data mining approach, Journal of Civil Engineering and Management 16(1): 75-84. http://dx.doi.org/10.3846/jcem.2010.07
Islam, M. D.; Faniran, O. O. 2005. Structural equation model of project planning effectiveness, Construction Management and Economics 23(2): 215-223. http://dx.doi.org/10.1080/0144619042000301384

Kaka, A. P.; Lewis, J.; Petros, H. 2003. The effects of the variability of project planning on cost commitment curves: a case study, Engineering, Construction and Architectural Management 10(1): 15-26. http://dx.doi.org/10.1108/09699980310466514

Kauppinen, M.; Vartiainen, M.; Kontio, J.; Kujala, S.; Sulonen, R. 2004. Implementing requirements engineering processes throughout organizations: success factors and challenges, Information and Software Technology 46(14): 937-953. http://dx.doi.org/10.1016/j.infsof.2004.04.002

Keller, R. T. 1994. Technology-information processing fit and the performance of $\mathrm{R} \& \mathrm{D}$ project groups: a test of contingency theory, Academy of Management Journal 37(1): 167-179. http://dx.doi.org/10.2307/256775

Kwak, Y. H.; Smith, B. M. 2009. Managing risks in mega defense acquisition projects: performance, policy, and opportunities, International Journal of Project Management 27(8): 812-820.

http://dx.doi.org/10.1016/j.ijproman.2009.02.002

Larson, E. W.; Gobeli, D. H. 1988. Organizing for product development projects, Journal of Product Innovation Management 5(3): 180-190. http://dx.doi.org/10.1111/1540-5885.530180

Laslo, Z. 2010. Project portfolio management: an integrated method for resource planning and scheduling to minimize planning/scheduling-dependent expenses, International Journal of Project Management 28(6): 609-618. http://dx.doi.org/10.1016/j.ijproman.2009.10.001

Laufer, A.; Woodward, H.; Howell, G. A. 1999. Managing the decision-making process during project planning, Journal of Management in Engineering 15(2): 79-84.

http://dx.doi.org/10.1061/(ASCE)0742-597X(1999)15:2(79)

Lee, S.; Thomas, S. R.; Tucker, R. L. 2005. The relative impacts of selected practices on project cost and schedule, Construction Management and Economics 23(5): 545553. http://dx.doi.org/10.1080/01446190500040232

Li, T.; Cavusgil, T. 2000. Decomposing the effects of market knowledge competence in new product export, European Journal of Marketing 34(1): 57-80. http://dx.doi.org/10.1108/03090560010306205

Litwin, M. S. 1995. How to measure survey reliability and validity. California: Sage Publications.

Mahdi, I. M.; Alreshaid, K. 2005. Decision support system for selecting the proper project delivery method using analytical hierarchy process (AHP), International Journal of Project Management 23 (7): 564-572. http://dx.doi.org/10.1016/j.ijproman.2005.05.007

Merrow, E. W. 1988. Understanding the outcomes of megaprojects: a quantitative analysis of very large civilian projects. RAND/R-3560-PSSP. California: The Rand Corporation.

Molenaar, K.; Washington, S.; Diekmann, J., 2000. Structural equation model of construction contract dispute potential, Journal of Construction Engineering and Management 126(4): 268-277.

http://dx.doi.org/10.1061/(ASCE)0733-9364(2000)126:4(268)

Müller, R.; Turner, J. R. 2007. Matching the project manager's leadership style to project type, International Journal of Project Management 25(1): 21-32. http://dx.doi.org/10.1016/j.ijproman.2006.04.003

Nunnally, J. C. 1978. Psychometric theory. $2^{\text {nd }}$ ed. New York: McGraw-Hill.

Oberg, R.; Probasco, L.; Ericsson, M. 2000. Applying requirements management with use cases. Rational Software White Paper. California: Rational Software Corporation. 
Okoli, C.; Pawlowski, S. D. 2004. The Delphi method as a research tool: an example, design considerations and applications, Information \& Management 42(1): 15-29. http://dx.doi.org/10.1016/j.im.2003.11.002

Ozdoganm, I. D.; Birgonul, M. T. 2000. A decision support framework for project sponsors in the planning stage of build-operate-transfer (BOT) projects, Construction Management and Economics 18(3): 343-353. http://dx.doi.org/10.1080/014461900370708

Pinto, J. K.; Slevin, D. P. 1988. Project success: definitions and measurement techniques, Project Management Journal 19(1): 67-72.

Procaccino, J.; Verner, J.; Overmyer, S.; Darter, M. 2002. Case study: factors for early prediction of software development success, Information and Software Technology 44(1): 53-62. http://dx.doi.org/10.1016/S0950-5849(01)00217-8

Radujković, M.; Vukomanović, M.; Dunović, I. B. 2010. Application of key performance indicators in South-Eastern European construction, Journal of Civil Engineering and Management 16(4): 521-530. http://dx.doi.org/10.3846/jcem.2010.58

Reed, A. H.; Knight, L. V. 2010. Effect of a virtual project team environment on communication-related project risk, International Journal of Project Management 28(5): 422-427. http://dx.doi.org/10.1016/j.ijproman.2009.08.002

Saaty, T. L. 1980. The analytical hierarchy process: planning, priority setting, resource allocation. New York: McGrawHill.

Saaty, T. L. 1988. Multicriteria decision making: the analytic hierarchy process. Pennsylvania: University of Pittsburgh.

Saaty, T. L. 1996. Decision making with dependence and feedback: the analytic network process. Pennsylvania: RWS Publications.

Schmidt, R. C. 1997. Managing Delphi surveys using nonparametric statistical techniques, Decision Sciences 28(3): 763-774. http://dx.doi.org/10.1111/j.1540-5915.1997.tb01330.x

Shenhar, J.; Dvir, D.; Levy, O. 1997. Mapping the dimensions of project success, Project Management Journal 28(2): $5-13$.

Sobotka, A.; Czarnigowska, A. 2005. Analysis of supply system models for planning construction project logistics, Journal of Civil Engineering and Management 11(1): 73-82.
Toor, S.; Ogunlana, S. O. 2010. Beyond the 'iron triangle': stakeholder perception of key performance indicators (KPIs) for large-scale public sector development projects, International Journal of Project Management 28(3): 228236. http://dx.doi.org/10.1016/j.ijproman.2009.05.005

Tseng, M.; Lin, R.; Chen, H. 2011. Evaluating the effectiveness of e-learning system in uncertainty, Industrial Management \& Data Systems 111(6): 869-889. http://dx.doi.org/10.1108/02635571111144955

Vidal, L.; Marle, F.; Bocquet, J. 2011. Measuring project complexity using the Analytic Hierarchy Process, International Journal of Project Management 29(6): 718-727. http://dx.doi.org/10.1016/j.ijproman.2010.07.005

Westerveld, E. 2003. The project excellence model, linking success criteria and critical success factors, International Journal of Project Management 21(6): 411-418. http://dx.doi.org/10.1016/S0263-7863(02)00112-6

Winch, G.. M.; Kelsey, J. 2005. What do construction project planners do?, International Journal of Project Management 23(2): 141-149.

http://dx.doi.org/10.1016/j.ijproman.2004.06.002

Wyk, R. V.; Bowen, P.; Akintoye, A. 2008. Project risk management practice: the case of a South African utility company, International Journal of Project Management 26(2): 149163. http://dx.doi.org/10.1016/j.ijproman.2007.03.011

Yang, J.; Wei, P. 2010. Causes of delay in the planning and design phases for construction projects, Journal of Architectural Engineering 16(2): 80-83.

http://dx.doi.org/10.1061/(ASCE)1076-0431(2010)16:2(80)

Yang, L.; Chen, J.; Huang, C. 2011. Requirements definition and management practice to improve project outcomes, Journal of Civil Engineering and Management 18(1): $114-124$. http://dx.doi.org/10.3846/13923730.2012.657340

Zowghi, D. 2002. Does global software development need a different requirements engineering process? in Proceedings of International Workshop on Global Software Development-ICSE 2002, 21 May, Orlando, Florida, 53- 55.

\section{Appendix A}

\section{Evaluation criteria for project requiremnts in the ANP model}

\section{Evaluation criteria for project design parameter:}

Structural requirements and design: Structural system, Seismic requirements; Foundation system; Corrosion control requirements/Required protective coatings; Client specifications (e.g. basis for design loads, vibration, deflection, etc.); Future expansion/flexibility considerations; Design loading parameter (e.g. live/dead loads, design loads, collateral load capacity, equipment/material loads, wind/snow loads, uplift); Functional spatial constraints.

Architectural design: Requirements for building location; Access requirements; Nature/character of building design (e.g. aesthetics, etc.); Construction materials; Acoustical considerations; Circulation considerations; Color/material standards; Floor to floor height.

Site survey: A topography map with the overall plot and site plan; Legal property descriptions with property lines; Drainage patterns; Definition of final site elevation; Benchmark control systems; Setbacks, access \& curb cuts; Proximity to drainage ways; Existing facility locations and conditions. 
Electrical and mechanical design: Power sources with available voltage \& amperage; Special lighting considerations (e.g. lighting levels, color rendition); Uninterruptable power source (UPS); Emergency power requirements; Ability to use daylight in lighting; Lightning/grounding requirements; Special ventilation or exhaust requirements; Equipment/space special requirements with respect to environmental conditions (e.g. air quality, special temperatures); Air circulation requirements; Indoor design conditions (e.g. temperature, humidity, pressure, air quality, etc.); Plumbing requirements.

Piping system requirements: Piping specialty items list; Piping system criteria; Valve list with tag numbers; Tie-in list for all piping tie-ins to existing lines; Piping stress analysis.

\section{Evaluation criteria for project plan:}

Owner approval requirements: Milestones for drawing approval by phase; Durations of approval cycle compatible with schedule; Individual(s) responsible for reconciling comments before return; Types of drawings/specifications; Purchase documents and contract documents.

Design plan and approval: Design and approvals sequencing of events.

Project design criteria: Level of design detail required; Climatic data; Codes and standards; Utilization of design standards; Sole source requirements for equipment or systems; Insurance underwriter requirements.

Evaluation of adjacent building: Type and size of adjacent buildings; Condition assessment of adjacent buildings.

Purpose of building use: Identify building uses or functions.

\section{Evaluation criteria for site information:}

Fire protection: Fire protection practices at the site; Available firewater supply (amounts and conditions); Fire monitors and hydrants.

Site life safety considerations: Special safety requirements unique to the site; Wind direction indicator devices; Access and evacuation plan; Available emergency medical facilities; Security considerations (site illumination, access control, etc.).

Safety management: Fire resistant requirements; Explosion resistant requirements; Area of refuge requirements in case of catastrophe; Safety and alarm requirements; Eye wash stations; Safety showers; Deluge requirements and foam; Fume hoods; Handling of hazardous materials; Isolation facilities; Emergency equipment access; Data or communications protection in case of disaster or emergency; Fall hazard protection; Gas hazard detection; Ventilation requirements for restrooms, offices, and industrial areas.

Safety procedures: Hazardous material handling; Interaction with the public; Working at elevations/fall hazards; Evacuation plans and procedures; Drug testing; First aid stations; Accident reporting and investigation; Pre-task planning; Safety orientation and planning; Safety incentives; Personal protective equipment.

Reliability philosophy: Critical systems redundancy; Architectural/structural/civil durability; Mechanical/electrical/ plumbing reliability.

\section{Evaluation criteria for project control:}

Project schedule control: Milestones; Unusual schedule considerations; Required submissions and/or approvals; Required documentation and responsible party; Baseline vs. progress to date; Critical pacing equipment delivery; Critical path activities; Contingency or "float time"; Permitting or regulatory approvals.

Project cost control: Financial (client/regulatory); Phasing or area sub-accounting; Capital vs. non-capital expenditures; Report requirements; Payment schedules and procedures; Cash flow projections/draw down analysis; Cost code scheme/strategy; Costs for each project phase; Periodic control check estimates; Change order management procedure, including scope control.

Project cost estimate: Construction contract estimate; Professional fees; Land cost; Furnishings; Administrative costs; Contingencies; Cost escalation for elements outside the project cost estimate; Startup costs including installation; Miscellaneous expenses.

Overview of work scope: This work statement overview is a complete narrative description of the project that is discipline-oriented and supports development of the project schedule and project cost estimate. It sets the limits of work by each involved party and generally articulates their financial, task, and contractual responsibilities. It clearly states both assumptions and exclusions used to define the scope of work.

Project control requirements: A functioning project control system is in place for managing project baselines using earned value techniques, variance analysis and effective reporting. 


\section{Evaluation criteria for project strategy:}

Human resource management: Adequacy of staffing level; Extent of training workforce; Extent of team-building activities; Extent of rewarding high performance staff.

Economic analysis: Long-term operating and maintenance costs; Resale/lease potential or in the case of institutional buildings, long term use plans; Analysis of capital and operating cost versus sales or occupancy and profitability.

Project strategy: Clearly defined project strategy.

Alternatives considerations: Major alternatives have been identified and viable alternatives have been analyzed. Items to evaluate include issues such as feasibility, stakeholder values, and safety.

Value-analysis process: Discretionary scope issues; Expensive materials of construction; Life-cycle analysis of construction methods and structure.

\section{Evaluation criteria for building programming:}

Identify materials: Identify material items with lead times that will impact the design for receipt of vendor information or impact the construction schedule with long delivery times.

Indoor rooms: Identify indoor rooms.

Open space requirements: Service dock areas and access; Passenger drop-off areas; Pedestrian walkways; Courtyards, plazas, or parks; Landscape buffer areas; Lobbies and entries; Postal and newspaper delivery; Waste removal; Interior aisle ways and corridors.

Windows and doors: Blocking of natural light; Glare reducing windows; Exterior louvers; Interior blinds; Doors.

Compartment requirements: Identify compartment requirements.

Li-Ren YANG. A Professor of Business Administration at Tamkang University. He received his doctoral degree from the University of Texas at Austin. Research interest includes project management.

Jieh-Haur CHEN. A Professor of Graduate Institute of Construction Engineering and Management at National Central University. He received his doctoral degree from the University of Wisconsin-Madison. Research interest includes information technology in construction.

Chung-Fah HUANG. An Associate Professor of Civil Engineering at National Kaohsiung University of Applied Sciences. He received his doctoral degree from National Central University, Taiwan. Research interests include human resource management in construction, engineering ethics, and outsourcing management. 